\title{
マンモグラフィ精度管理用ファントム画像のコンピュータを用いた画質評価 2 台のフィルム・デジタイザについての比較
}

金沢大学病院放射線部 ${ }^{1)}$, 聖マリアンナ医科大学放射線医学 ${ }^{21}$

茨城県立医療大学 ${ }^{3)}$, 聖マリアンナ医科大学病院画像診断センター4)

聖マリアンナ医科大学乳腺内分泌外科 ${ }^{5)}$, 大阪警察病院人間ドッククリニック ${ }^{6}$

愛知県がんセンター中央病院 ${ }^{7}$, 福岡大学医学部放射線 医学教室 ${ }^{81}$

東北大学医学系研究科腫瘍外科 ${ }^{9)}$, NPO 法人マンモグラフィ検診精度管理中央委員会 ${ }^{10)}$

\begin{tabular}{|c|c|c|c|c|c|c|}
\hline 山本 友行 ${ }^{1)}$ & 今村 & 惠子 ${ }^{2,10)}$ & 藤崎 & 達也 ${ }^{3)}$ & 大内 & 幸敏 ${ }^{4)}$ \\
\hline 善弘 ${ }^{4)}$ & 福田 & 護 5,10$)$ & 中島 & 康雄 ${ }^{2)}$ & 寺田 & 央 $^{6,10)}$ \\
\hline 勝平 ${ }^{7,10)}$ & 岡崎 & 正敏 ${ }^{8,10)}$ & 大内 & 憲明 ${ }^{9,10)}$ & & \\
\hline
\end{tabular}

マンモグラフィ検診に関わる施設画像評価で認定された施設は2005年10月末で521施設 であり，マンモグラフィ検診を実施している2,500施設(推定)の $20 \%$ 程度である。したが って, 今後施設画像評価を受ける施設としては, 未認定の約 2,000 と認定を更新する施設 が存在する。

$\mathrm{S} / \mathrm{F}$ 系でのファントム画像については数量的な画質評価(フィルムをデジタイザにて読 みとり，テスト物質の写真コントラストを画像処理ソフトを用いて計測する方法）も行っ ている。現在は画像の読みとりにデジタイザ 1 台で対応しているが, 安定した評価システ ムを構築するためには, 複数のデジタイザを使用できる体制が不可欠である。今回, 2 台 のデジタイザを使用して読みとった画像について, 数量的な画質評価を行い, 比較検討し た。

デジタイザはVXR-12 plus と Model 2905, 開口径を $85 \mu \mathrm{m}$ (公称), 画像フォーマットは TIFF とした。解析には IP Labを使用した。3 個の RMI 156型ファントムを撮影して得 られた34画像について石灰化, 腫瘤を評価した。画質評価は計測された写真コントラスト を到達度(基準画像に対する相対值)に変換することにより行った。その変換によりデジタ イザ間の差異は著しく軽隇された。両デジタイザ間の相関係数は石灰化平均到達度で 0.970 , 腪瘤平均到達度で 0.915 であった。また, 現行の基準で合否判定をすると石灰化で $33 / 34$, 腫瘤で $31 / 33$ 画像, 総合では $34 / 34$ が一致し, 2 台のデジタイザについて $90 \%$ 以の 一致率で評価できることが示された。

到達度による画質評価を行うことにより, 現在使用しているデジタイザと異なる機種を 使用しても, 一定の条件や較正, 手順のもとに現在と同等の評価を継続できる可能性が示 唆された。

Key words：マンモグラフィ, 画質評価, ファントム画像, デジタイザ, 整合性

\section{緒 言}

マンモグラフィを用いた乳がん検診において，

別冊請求先： $=920-8641$ 金沢市宝町13-1 金沢大 学医学部附属病院放射線部 山本友行

E-mail address : tomoyama@med.kanazawa-u.ac.jp
マンモグラフィ実施施設の要件として線量基準と

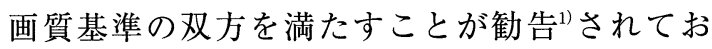
り，2001年 3 月31日付けで厚生労働省から通達さ れている(老健 65 号 $)^{2)}$ 。

乳房撮影時の線量と画質の評価は NPO 法人マ ンモグラフィ検診精度管理中央委員会 (以下, 精 中委)によって行われ，2001年 4 月から実施され 
ている。現在，施設画像評価は申し込みのあった 施設を対象に行っており，2005年10月末現在で認 定された施設は521施設3)である。検診に使用され ている乳房エックス線撮影装置は約 2,500 台と推 定されており，認定施設はその $20 \%$ 程度である。 したがって，未だ認定されていない約 2,000 台 $(\fallingdotseq$ 2,000 施設)，ならびに認定を更新する施設をあわ せて, 施設画像評価を受ける施設が増加すること が予想される。

画質評価ではファントム画像と臨床画像の評価 が行われているが，スクリーン/フィルム系で撮 影されたファントム画像については視覚評価を補 完するものとして数量的な画質評価を行ってい る ${ }^{1)}$ 。数量的な画質評価では, フィルムをデジ夕 イズした画像について，テスト物質のコントラス トを画像処理ソフトを用いて計測している゙)。さ らに，各画像のコントラストを基準となる画像の コントラストに対する相対值 (到達度) ${ }^{1,5)}$ で表して いる。現在はフィルム画像の読みとりにはフィル ム・デジタイザ 1 台(VXR-12 plus)で対応してい るが, 装置の故障, 評価数の増加を考えた場合, 安定した評価体制を維持するためには，複数のデ ジタイザを使用する体制が不可欠である ${ }^{6)}$ 。複数 のデジタイザを使用した場合に現在行っている評 価の整合性を保てるか検証するために，今回，2 台のデジタイザを使用し，画質評価した結果を比 較検討したので報告する。

\section{1. 対象と方法}

フィルム画像の読み取りは 2 台のデジタイザ (表 1)により, いずれも開口径 $85 \mu \mathrm{m}$ (公称)で行 い, 画像フォーマットは TIFF(Tagged-Image File Formatの略。DICOM 出力された画像は TIFFに

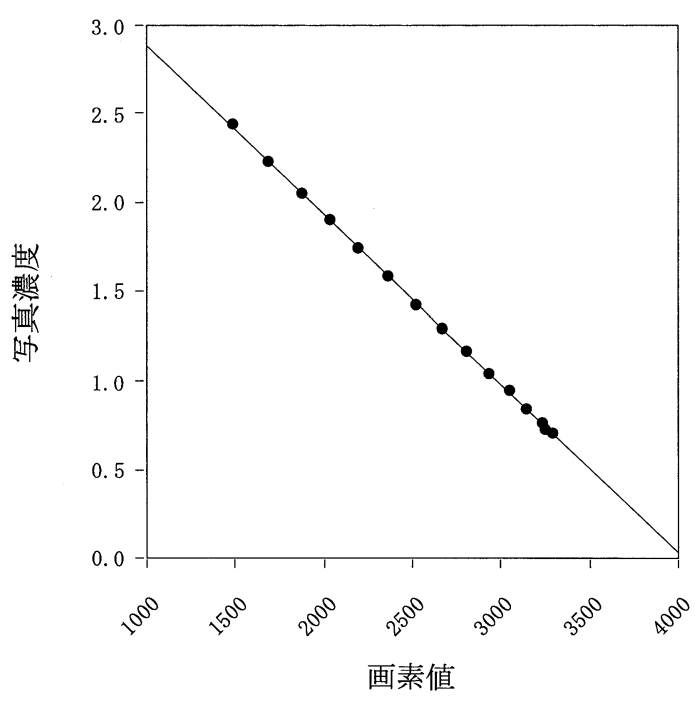

図 1. 画素值-写真濃度の較正曲線. デジタイザ Model 2905について．濃度範囲は0.73から2.44.

変換)で保存した。画素值を写真濃度に変換する ため, 濃度階調フィルム (写真濃度 $0.6 \sim 2.6$ の 16 階調。レーザプリンタ出力)を用いてデジタイザ ごとに較正曲線 ( 1 例を図 1 に示す)を作成した。 解析には画像処理ソフトウエア IP Lab (Ver.3.5.4, Scanalytics, US)を使用し，ファン トムに含まれる所定のテスト物質について写真コ ントラスト (テスト物質とその近傍の写真濃度の 差)を算出した。画質は施設画像評価で行われて いるのと同様に, 各画像におけるテスト物質個々 の写真コントラストを基準画像のそれに対する相 対的な值 $(\text { 到達度 })^{5)}$ で表現した。

対象とした画像は RMI 156型 (Gammex,US) フ アントム 3 個 (テスト物質が包埋されているワッ クス板の番号はそれぞれ705-064，706-037，707054）を撮影したものである。解析したのは基準画 像 (精中委の施設画像評価で使用されている) 計 3

表 1. 使用したフィルムデジタイザ

\begin{tabular}{|c|c|c|c|}
\hline 型式 & メーカ & $\begin{array}{c}\text { 深さ } \\
\text { (bit/pixel) }\end{array}$ & 光源 \\
\hline VXR-12 plus & Vidar Systems, Co. & 8 & ハロゲンランプ \\
\hline Model 2905 & Array Corporation & 12 & $\begin{array}{l}\mathrm{He}-\mathrm{Ne} \text { レーザ } \\
\text { (波長633nm) }\end{array}$ \\
\hline
\end{tabular}


画像, ならびに他の34施設で撮影された画像(そ れぞれ13，10，11画像，合計34画像)である。い

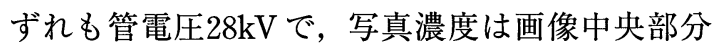
で1.4〜1.5となるようスクリーン/フィルム法で 撮影された画像である。解析の対象としたテスト 物質は模擬石灰化の $1 \sim 3$ 群 (直径 $540 \mu \mathrm{m}, 400$ $\mu \mathrm{m}, 320 \mu \mathrm{m})$, および模擬腫瘤の $1 \sim 3$ 番目 (厚 さ $2.00 \mathrm{~mm}, 1.00 \mathrm{~mm}, 0.75 \mathrm{~mm})$ である。

\section{2. 結 果}

图 2 はファントム 3 個のうち 1 個 (ワックス板 の番号705-064)を撮影した13画像について, 模擬 石灰化と模擬腫瘤 (およびディスク)の写真コント ラストを 2 台のデジタイザについて比較したもの である。回帰係数および相関係数は石灰化で $0.954,0.981$, 腫瘤で $0.945,0.998$ であった。腫 瘤については 2 台のデジタイザでほぼ等しい数值 を示したが，石灰化はVXR-12 plus に比べ Model 2905で読みとられたほうが高い数值を示した。

2 台のデジタイザで読みとって解析した 34 画像 の模擬石灰化 ( 1 から 3 群, 計102群) と模擬腫瘤 （1 から 3 個目, 計99個。1 枚の画像は腫瘤部分 のアーチファクトが強く, 対象外とした)の到達 度を比較した(図 3,4)。各テスト物質について回 鹵係数と相関係数はそれぞれ次のとおりであっ

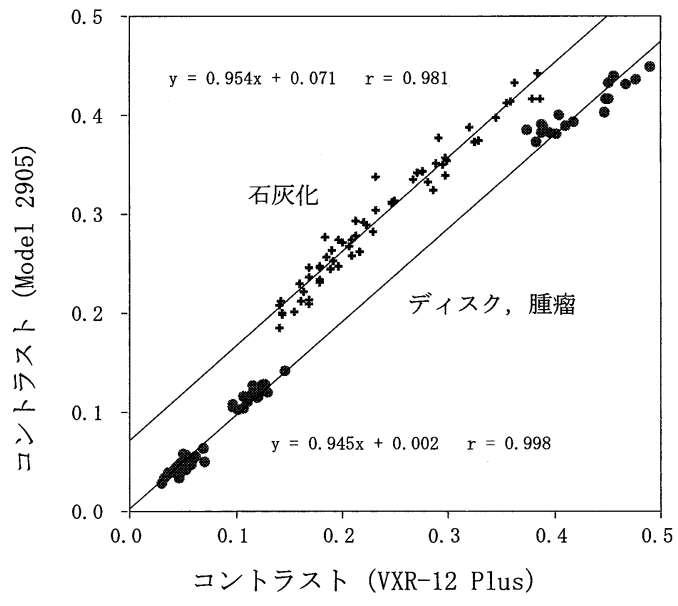

図 2. 2台のデジタイザの比較. 模擬石灰化と模擬 腫瘤の写真コントラスト(文献 7 より).

た; 石灰化 1 群は $0.876,0.950$,石灰化 2 群は $0.769 ， 0.956$, 石灰化 3 群は $0.835 ， 0.859$ ，また, 腫瘤 1 は0.758, 0.870, 腫瘤 2 は $1.085,0.849$, 腫瘤 3 は0.903，0.893。また，石灰化 1 から 3 群 をまとめた石灰化到達度の回帰係数と相関係数は 0.890，0.970(図 5)，腫瘤 1 から 3 をまとめた腫 瘤到達度についてはそれぞれ0.996，0.915(図 6) と, 相関は腫瘤に比べ石灰化の方が高かった $(\mathrm{P}$ $=0.04$, d. o. f. $=33)$ 。そして, 石灰化 $1 \sim 3$ 群 と腫瘤 $1 \sim 3$ 個目を平均した総合到達度では 2 台

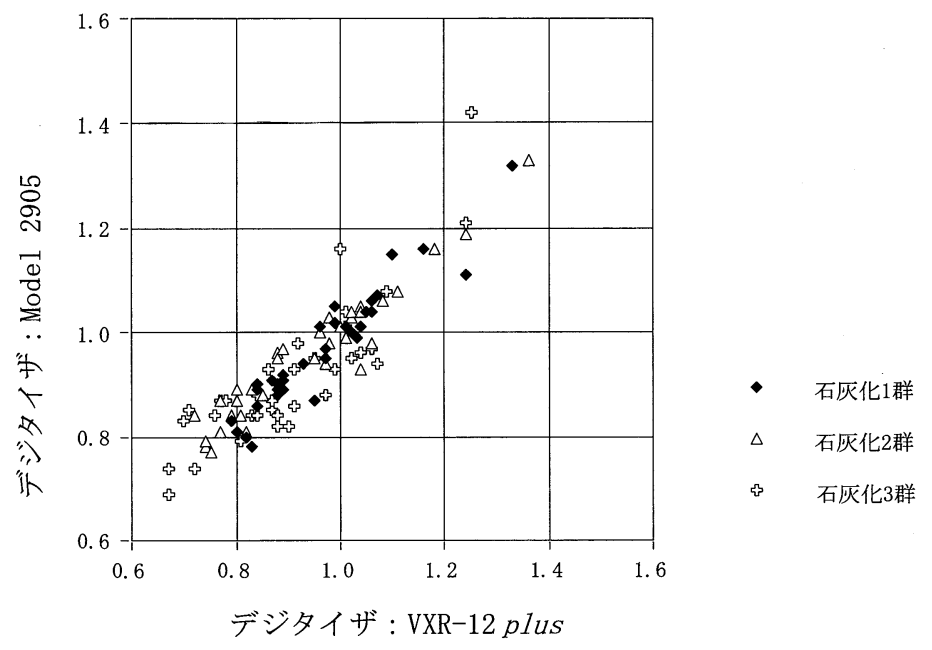

図 3. 2 台のデジタイザにより読みとった画像の数量的な画質評価 の比較一模擬石灰化第 $1,2,3$ 群それぞれの到達度. 


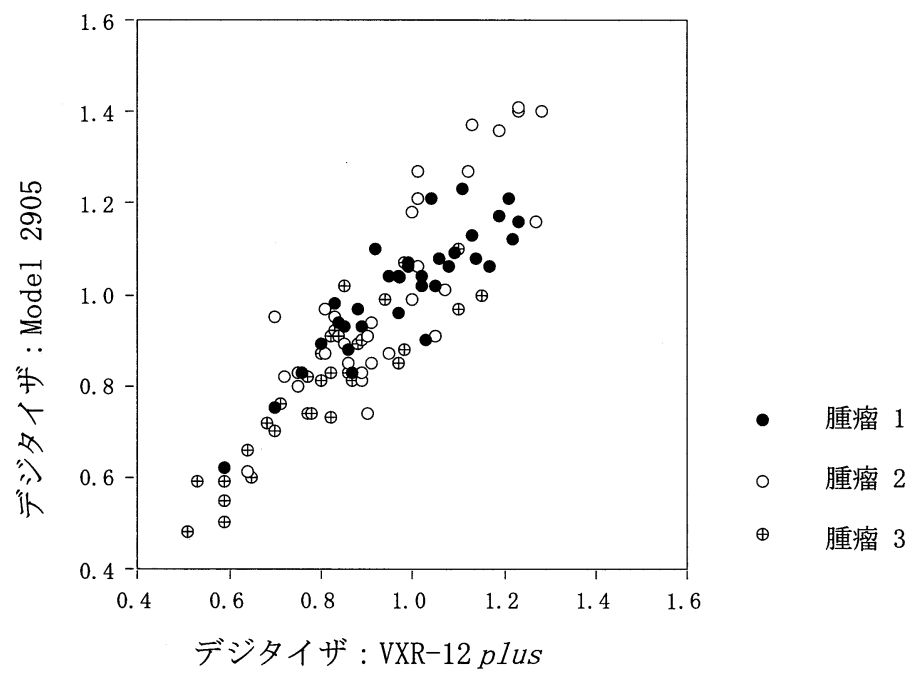

図 4. 2 台のデジタイザにより読みとった画像の数量的な画質評価 の比較一模擬腫瘤 $1,2,3$ 個目それぞれの到達度. 石灰化よりも バラツキが大きい。

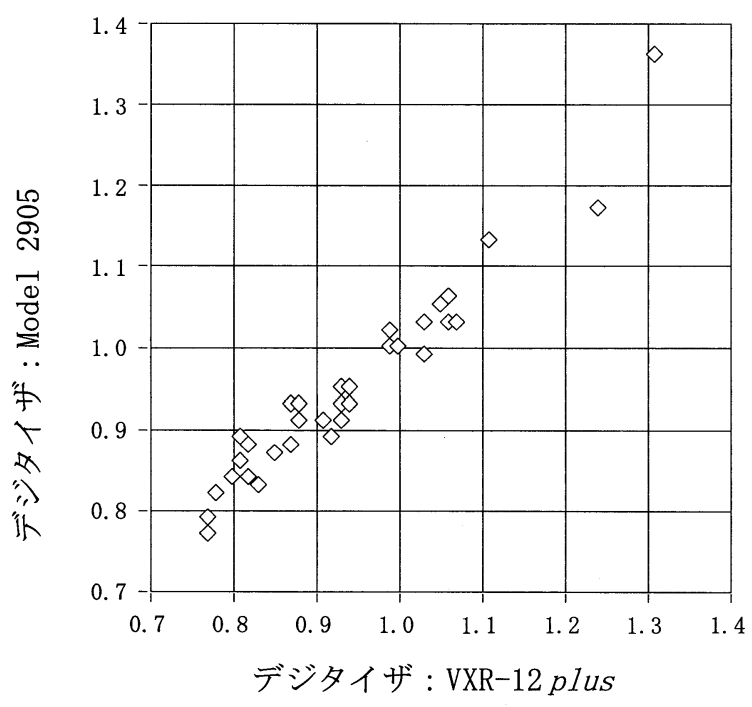

図 5. 2 台のデジタイザにより読みとった画像の数 量的な画質評価の比較一石灰化到達度につい て. 相関係数は 0.970 .

のデジタイザ間の回帰係数と相関係数は 0.930，0.966(図 7)であった。

精中委による施設画像評価においては, スクリ ーン/フィルム法で撮影されたファントム画像の 数量的な画質評価による合否基準は到達度 0.8 と されている ${ }^{1)}$ 。その基準で判定した結果を 2 台の

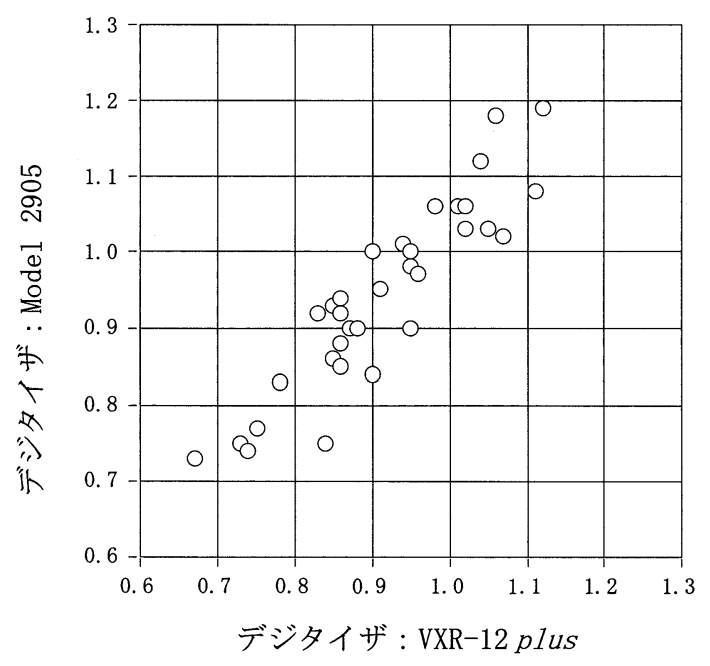

図 6. 2 台のデジタイザにより読みとった画像の数 量的な画質評価の比較一腫瘤到達度について. 相関係数は0.915.

デジタイザについて表 2 に示した。石灰化につい ては, 両者で判定が一致したのは33画像 $(97.1 \%)$ ，一致しなかった 1 画像では到達度は 2 台のデジタイザでそれぞれ0.78と0.82であった。 一方, 腫瘤については31画像 (93.9\%)の判定が一 致し, 不一致であった 2 画像の到達度は 0.84 と 0.75 , ならびに 0.78 と 0.83 であった。なお, 総合 


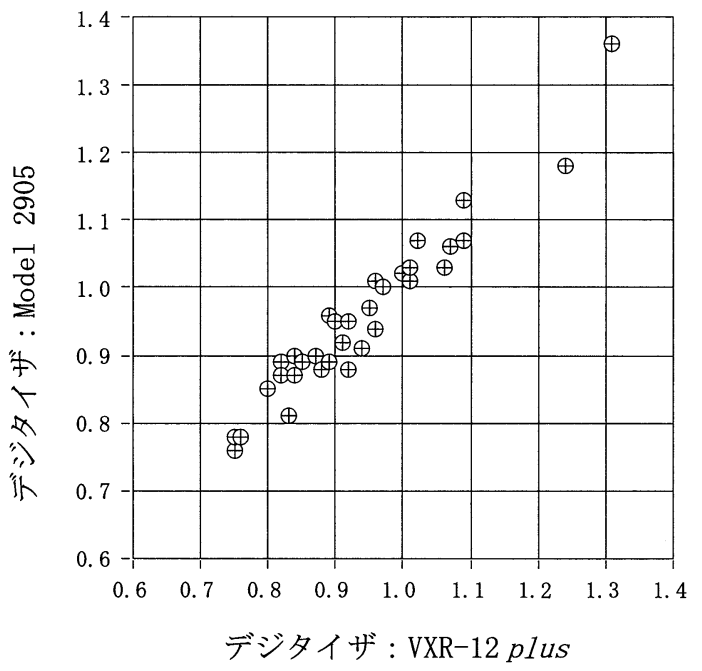

図 7. 2 台のデジタイザにより読みとった画像の数 量的な画質評価の比較一石灰化と腫瘤の総合到 達度について．相関係数は 0.966 .

到達度でみた判定は34画像(100\%)について一致 した。

\section{3. 考 察}

2 台のデジタイザにより読みとられた画像につ いて, 写真コントラストを比較すると, 腫瘤につ いては両者の值に良好な一致がみられたが，石灰 化については系統的な差が認められた(図 2)。こ の理由としては, 開口径(公称) は両デジタイザに ついて $85 \mu \mathrm{m}$ と等しく設定したものの，おそらく 実効的な径が VXR-12 plus のほうが Model 2905 よりも大きく，それが石灰化の読みとりに影響し たものと推測される。だが, 現在, 施設画像評価 で行われているように到達度(基準画像の写真コ ントラストとの相対值)で評価することにより, 石灰化の写真コントラストについて見られた 2 台 のデジタイザ間での系統的な差は解消し, 将来, 複数のデジタイザを併用して画質評価を行う場合 においても，整合性を向上できる方法であると考 える。

2 台のデジタイザにより読みとられた画像を到 達度による画質評価で比較した結果，石灰化の相 関が腫瘤の相関よりも高かった。また, 到達度の
表 2. 数量的な画質評価(注)による判定結果の比較. 2 台のデジタイザにより画像を読みとり, 到達度 の合否判定基準を 0.8 とした場合.

\begin{tabular}{|c|c|c|c|}
\cline { 3 - 4 } \multicolumn{2}{c|}{ 石灰化 } & \multicolumn{2}{|c|}{ デジタイザ $2^{*}$} \\
\cline { 3 - 4 } \multicolumn{2}{c|}{} & 0.8 以上 & 0.8 未満 \\
\hline \multirow{2}{*}{ デジタイザ $1{ }^{*}$} & 0.8 以上 & 31 & 1 \\
\cline { 2 - 4 } & 0.8 未満 & 0 & 2 \\
\hline
\end{tabular}

\begin{tabular}{|c|c|c|c|}
\hline \multirow{2}{*}{\multicolumn{2}{|c|}{ 望 瘤** }} & \multicolumn{2}{|c|}{ デジタイザ $2^{*}$} \\
\hline & & 0.8 以上 & 0.8 未満 \\
\hline \multirow{2}{*}{ デジタイザ $1^{*}$} & 0.8 以上 & 27 & 1 \\
\hline & 0.8 未満 & 1 & 4 \\
\hline
\end{tabular}

\begin{tabular}{|c|c|c|c|}
\hline \multirow{2}{*}{\multicolumn{2}{|c|}{ 総 合 }} & \multicolumn{2}{|c|}{ デジタイザ $2^{*}$} \\
\hline & & 0.8 以上 & 0.8 未満 \\
\hline \multirow{2}{*}{ デジタイザ $1^{*}$} & 0.8 以上 & 31 & 0 \\
\hline & 0.8 未満 & 0 & 3 \\
\hline
\end{tabular}

（注）フィルムをデジタル化し，画像処理ソフトによ りテスト物質の写真コントラストを測定. テスト物 質個々の写真コントラストを基準画像のそれに対す る相対的な值で表現(到達度)した. 石灰化は画像毎 に $1 \sim 3$ 群の平均, 腫瘤も $1 \sim 3$ 個目の平均到達度 により判定した. 総合は, 石灰化 $1 \sim 3$ 群, 腫瘤 1 $\sim 3$ 個目の平均到達度とした。

合否基準值を 0.8 とした場合，石灰化 $(1 \sim 3$ 群の 平均到達度) で $33 / 34$, 腫瘤 $(1 \sim 3$ 個目の平均到達 度)で31/33の一致をみた。腫瘤に比べ石灰化のほ うが判定の一致率は高めであった。今回対象とし た画像に関する限り，テスト物質の写真コントラ ストは，石灰化は 0.31 ( 1 群) から 0.17 ( 3 群)であ り，腫瘤は0.12( 1 個目)から 0.05 ( 3 個目)であっ た。このように, 1 個目の腫瘤でも石灰化 3 群よ りコントラストが低く，写真コントラストが高い 物質について一致がよい傾向にある，という結果 であった。 


\section{結 語}

ファントム画像の画質の数量的な評価におい て，フィルムの読みとりに型式の異なる 2 台のデ ジタイザを用いた場合の影響を比較検討した。画 質評価に異なるデジタイザを使用した場合には評 価結果の整合性の担保が課題である。到達度(基 準とする画像に対する相対值)で画質を評価する 手法により，デジタイザ間の差違は相当解消さ れ，90\%以上の一致率で評価できることが今回の 研究で示された。したがって，デジタイザの要件 や手順・較正などについて一定の標準化は必要で あるが，複数のデジタイザを使用することによ り，施設画像評価の体制を強化することができる と考える。

なお, 本研究の予備的な結果は第12回日本乳癌 検診学会総会 (2002年11月21，22日，鹿児島)にて 発表したが(6), その後, 厚生労働省がん研究助成 金大内班(「乳がん検診の精度及び効率の向上に関 する研究」平成 15 年度 $)^{7)}$ の一環として継続して行 われた。

\section{【文 献】}

1）大内憲明編：マンモグラフィによる乳がん検診 の手引き——精度管理マニュアル。日本医事新
報社，2000

2 ）厚生労働省通達老健第65号：「がん予防重点教 育及びがん検診実施のための指針」の一部改定 について。2001年 3 月31日

3 ) 森本忠興, 福田 護, 岡崎正敏, 他: マンモグ ラフィ検診精度管理中央委員会の現状と課題 （1）：マンモグラフィ検診精度管理中央委員会 の現状. 日乳癌検診学会誌, 15：4-11, 2006

4) 今村惠子, 福田 護, 塚本 浩, 他：マンモグ ラフィ精度管理のためのファントム画像デー夕 ベース——第 1 報：画像データベース構築と画 像処理を利用した画質評価. 日乳癌検診学会 誌， $6 ： 271-279 ， 1997$

5 ）今村惠子, 福田 護, 塚本 浩, 他：マンモグ ラフィ精度管理のためのファントム画像データ ベース—第 2 報 : デジタル化と ACR ファント 厶の諸問題. 日乳癌検診学会誌, $7: 103-$ 112, 1998

6 ) 今村惠子, 山本友行, 藤崎達也, 他 : 複数施設 における画質のデジタル評価一一施設間の整合 性確立に向けて. 第12回日本乳癌検診学会総 会, 2002年11月 (鹿児島)

7 ）今村惠子, 山本友行, 藤崎達也, 他: 精度管理 ファントムのコンピュータによる画質評価— 展開の拡大に対する対応. 厚生労働省がん研究 助成金による「乳がん検診の精度及び効率の向 上に関する研究」(H15-14, 主任研究者大内憲明) 平成15年度研究報告. 2004, pp. 38-41 


\title{
Subjective Evaluation of Mammography Phantom Image Quality : Comparison of Images Read by Two Digitizers
}

\author{
Tomoyuki Yamamoto $^{1)}$, Keiko Imamura ${ }^{2,10)}$, Tatsuya Fujisaki ${ }^{3)}$, Yukitoshi Ohuchi ${ }^{4)}$, Yoshihiro Kato ${ }^{4)}$, \\ Mamoru Fukuda ${ }^{5,10)}$, Yasuo Nakajima ${ }^{2)}$, Hiroshi Terada ${ }^{6,10)}$, Katsuhei Horita ${ }^{7,10)}$, Masatoshi Okazaki ${ }^{8,10)}$, \\ Noriaki Ohuchi, ${ }^{9,10)}$
}

Kanazawa University Hospital ${ }^{1}$, Department of Radiology ${ }^{2)}$ St. Marianna University School of Medicine, Ibaraki Prefectural University ${ }^{3)}$, St. Marianna University Hospital ${ }^{4)}$,

Department of Breast Surgery ${ }^{5}$, St. Marianna University School of Medicine,

Osaka Police Hospital $^{6)}$, Aichi Cancer Center ${ }^{7)}$, Fukuoka University ${ }^{8)}$, Tohoku University ${ }^{9)}$,

The Central Committee on Quality Control of Mammographic Screening ${ }^{10)}$, A Nonprofit Organization

In breast cancer screening in Japan, the quality of mammographic sites is assessed by The Central Committee on Quality Control of Mammographic Screening, a nonprofit organization, and 521 screening centers were certified as of October 2005. However, about 2,000 screening centers with mammography units have still not been certified. In the evaluation procedure, phantom images obtained by a screen-film system are subjected to both visual and computerized objective inspection. Up to now, only one digitizer has been used for film reading, but in future multiple digitizers will become necessary to process the increased number of images and to cope with a trouble of the digitizer or computer system. In this study, images read by two digitizers were analyzed using the same method as that devised by the Committee, and compared with each other.

The digitizers employed were the VXR-12 plus and Model 2905, with an aperture size of $85 \mu \mathrm{m}$, TIFF format, and IP Lab for image analysis. Calcification specks and masses in 34 images of $3 \mathrm{RMI}-$ 156 phantoms were studied. Systematic deviations of the radiographic contrast of specks were cancelled by converting the radiographic contrast to "performance level", which is an index relative to a standard image. The correlation coefficient between the two digitizers was 0.970 for specks and 0.915 for masses. Pass-or-fail decisions were agreed for 33 of 34 images of specks and 31 of 33 images of masses.

The results showed agreement of greater than $90 \%$, indicating that it is practical to use multiple digitizers to read film images for image quality assessment under the control of an established procedure.

Key words : mammography, image quality evaluation, phantom, digitizer, consistency 